Research Article Plant Genetics

\title{
Overexpression of AtNCED3 gene improved drought tolerance in soybean in greenhouse and field conditions
}

Mayla Daiane Correa Molinari ${ }^{1,2^{*}}$, Renata Fuganti-Pagliarini ${ }^{2 *}$ iD, Silvana Regina Rockenbach Marin ${ }^{1,2}$, Leonardo Cesar Ferreira ${ }^{2}$, Daniel de Amorim Barbosa ${ }^{1,2}$, Juliana Marcolino-Gomes ${ }^{2}$, Maria Cristina Neves de Oliveira ${ }^{2}$, Liliane Marcia Mertz-Henning ${ }^{2}$, Norihito Kanamori ${ }^{3}$, Hironori Takasaki ${ }^{4}$, Kaoru Urano ${ }^{4}$, Kazuo Shinozaki $^{4}$, Kazuo Nakashima ${ }^{3}$, Kazuko Yamaguchi-Shinozaki ${ }^{5}$ and Alexandre Lima Nepomuceno ${ }^{2}$

${ }^{1}$ Universidade Estadual de Londrina, Departamento Geral de Biologia, Londrina, PR, Brazil.

${ }^{2}$ Embrapa Soja, Londrina, PR, Brazil.

${ }^{3}$ Japan International Research Center for Agricultural Sciences, Biological Resources and Post-harvest

Division, Tsukuba, Ibaraki, Japan.

${ }^{4}$ RIKEN Center for Sustainable Resource Science, Gene Discovery Research Group, Tsukuba, Ibaraki, Japan.

${ }^{5}$ The University of Tokyo, Laboratory of Plant Molecular Physiology, Department of Applied Biological Chemistry, Bunkyo-ku, Tokyo, Japan.

\begin{abstract}
Water deficit is an important climatic problem that can impair agriculture yield and economy. Genetically modified soybean plants containing the AtNCED3 gene were obtained aiming drought-tolerance improvement. The NCED3 gene encodes a 9-cis-epoxycarotenoid dioxygenase (NCED, EC 1.13.11.51), an important enzyme in abscisic acid biosynthesis. ABA activates the expression of drought-responsive genes, in water-deficit conditions, targeting defense mechanisms and enabling plants to survive under low water availability. Results from greenhouse experiments showed that the transgene AtNCED3 and the endogenous genes GmAREB1, GmPP2C, GmSnRK2 and GmAAO3 presented higher expression under water deficit (WD) in the event $2 \mathrm{Ha} 11$ than in WT-plants. No significant correlation was observed between the plant materials and WD conditions for growth parameters; however, gas exchange measurements decreased in the GM event, which also showed $80 \%$ higher intrinsic water use when compared to WT plants. In crop season 2015/16, event 2Ha11 showed higher total number of pods, higher number of pods with seeds and yield than WT plants. ABA concentration was also higher in GM plants under WD. These results obtained in field screenings suggest that AtNCED3 soybean plants might outperform under drought, reducing economic and yield losses, thus being a good candidate line to be incorporated in the soybean-breeding program to develop droughttolerant cultivars.
\end{abstract}

Keywords: Glycine max L. Merrill, water deficit, abscisic acid, gas exchange measurements, RT-qPCR.

Received: August 29, 2019; Accepted: April 6, 2020.

\section{Introduction}

Brazil is the second country in the worldwide production and processing of soybeans, and the second largest exporter of grains and oil (Aprosoja, 2016). This productive chain generates 1.4 million jobs, consisting of the main contributor to the Brazilian Gross Domestic Product (GDP) (IBGE, 2016). According to IBGE (Brazilian Institute for Geography and Statistics), in 2015, agriculture was the only economic sector that did not reduce its contribution to GDP, increasing $1.8 \%$ in relation to the previous year, on the influence of soybeans and corn (FAO, 2016).

Correspondence to Renata Fuganti-Pagliarini. Embrapa Soja, Rodovia Carlos João Strass - Distrito de Warta, PO. Box 231 86001-970, Londrina, PR, Brazil. E-mail: renatafuganti@gmail.com *These authors contributed equally.
Despite the positive numbers, the increased frequency and intensity of drought periods have generated recurrent and significant losses in soybean yield, indicating that sustainable crop production is highly dependent on the development of cultivars more tolerant to water deficit (WD), which can be obtained through available genetic engineering techniques. Many genes conferring drought tolerance had been identified under the current global climate change scenario (Ramiro et al., 2016), and many of them were introduced in important crops. However, sometimes the proof of drought tolerance improvement in real field conditions is not achieved, keeping the GM events characterization only in greenhouse.

Plants have two main regulatory pathways for drought responses: an ABA-dependent and an ABA-independent pathway (Shinozaki and Yamaguchi-Shinozaki, 2007). Be- 
sides controlling several plant development processes, the ABA hormone coordinates an intricate regulatory network that enables plants to survive under short-water availability conditions (Kim et al., 2010). Under WD, ABA levels increase in the plant system, which leads ABA to bind to specific receptors (PYLs) forming a complex with other enzymes (PP2Cs and SnRKs). This binding of ABA releases kinases that bind to specific transcription factors (TFs) such as $\mathrm{ABRE} / \mathrm{ABFs}$, which target drought-responsive genes expression, activating defense mechanisms (Barbosa et al., 2013; Cao et al., 2013; Takeuchi et al., 2014; Park et al., 2015), such as stomatal closure, and synthesis of osmoprotectants enzymes (Sah et al., 2016).

Several studies have reported (Iuchi et al., 2001; Endo et al., 2008), a better performance of plants under WD overexpressing genes that encode enzymes of the ABA biosynthetic pathway, in particular the NCED3 gene, which encodes 9-cis-epoxycarotenoid dioxygenase (NCED, EC 1.13.11.51), a central enzyme in ABA biosynthesis (Bhaskara et al., 2012; Behnam et al., 2013). The overexpression of AtNCED3, in Arabidopsis, increased endogenous ABA levels, targeted the transcription of drought- and ABA-inducible genes, reduced transpiration rate, and improved drought tolerance in the GM plants (Iuchi et al., 2001). The NCED3 gene has also been described to be strongly induced in WD, under greenhouse conditions, in several economically important crops such as avocado (Persea americana) (Chernys and Zeevaart, 2000), citrus (Citrus sinensis) (Rodrigo et al., 2006; Neves et al., 2013; Pedrosa et al., 2015), common bean (Phaseolus vulgaris) (Qin and Zeevaart, 1999), cowpea (Vigna unguiculata) (Iuchi et al., 2000), peanuts (Arachis hypogaea) (Wan and Li, 2006), tomato (Solanum lycopersicum) (Burbidge et al., 1999), and turmeric (Curcuma longa) (Ahrazem et al., 2012).

In soybean, no information regarding GM plants with the NCED gene is available. Thus, considering the eminent need for plants more tolerant to WD periods in the future scenario of world climate changes, our main objective was to develop GM soybeans with improved drought tolerance by introducing the AtNCED3 gene into a conventional soybean cultivar. Under greenhouse conditions, these plants were submitted to WD, and ABA content was quantified in leaves. In addition, the GM plants were submitted to WD induced under real field conditions for two crop seasons. As in greenhouse environment, growing conditions can be monitored; plants behavior may not reproduce accurately the way plants outperform water deficit over a complete growing-season in a real field spot (Passioura, 2012). Therefore, it's important to challenge the applied strategy to cope with drought, in water-sensitive phases such as flowering - pod-filling, when plants require 7-8 mm of water daily; and water scarcity implies in significant production losses (Berlato et al., 1986; Embrapa, 2015). Moreover, as in other countries, prior to approving a commercial product, regulatory bodies such as the Brazilian National Technical Biosafety Commission requests tests in field conditions. Thus, with these lines in field can speed up the deregulamentation process.
Therefore, our work brings new insights into how the overexpression of a gene encoding NCED enzyme from ABA biosynthesis acts in WD tolerance in soybean plants, and how these GM lines perform in field conditions, where and when data can precisely gauge whether the technology is efficacious. These data might help soybean breeders to indicate the best performing lines in real crop circumstances to introduce them into breeding programs aiming to develop a cultivar to be used and marketed to soy producers.

\section{Material and Methods}

\section{Biological material and identification of GM plants positive to 35S:AtNCED3}

Vectors pMDC123-GI and pC3300J-35S (Cambia Enabling Innovation) were used as backbone to construct the expression cassette contained the AtNCED3 gene. This cassette was introduced, via electroporation; into the A. tumefaciens strain EHA 105 (Hood et al., 1993) as described by Casali and Preston (2003). This vector is under the control of the constitutive promoter CaMV 35S (Cauliflower mosaic virus) and TNOS terminator (A. tumefaciens nopaline synthase). The marker genes present in the cassette are bar gene (phosphinothricin acetyl transferase), used as a selective agent once it confers resistance to ammonium glufosinate herbicide; and NPTII gene (Neomycin phosphotransferase), which confers resistance to the antibiotic kanamycin, and was applied to select colonies carrying the inserted transgene (Figure S1).

The BRS 184 (wild type (WT) - genetic background) conventional soybean cultivar was transformed using the Agrobacterium tumefaciens method described by Paz et al. (2006). Aiming at improving injury for infection, a protocol modification was introduced; using a stainless-steel micro brush, each cotyledon was scratched 10 to 12 times.

During the selection process, the seedlings that developed well were transferred to a mixture of substrate/sand (1:1), with the substrate comprising soil/sand/organic compounds at 3:2:2 parts. The seedlings were then acclimated for at least 1 week in a growing chamber and subsequently transferred to a greenhouse, where molecular evaluations were performed.

A conventional PCR using a set of primers A (Table S1A) was carried out to confirm positive plants. The genomic DNA was extracted from leaf tissues, according to Doyle and Doyle, 1987. PCR reactions were carried out in a final volume of $25 \mu \mathrm{L}$ and were composed of $5 \mu \mathrm{M}$ of each forward and reverse primer, $0.4 \mathrm{mM}$ dNTPs, $2 \mathrm{mM}$ magnesium chloride, $1 \mathrm{U}$ Taq DNA polymerase, and $50 \mathrm{ng} \mu \mathrm{L}^{-1}$ DNA. Amplifications were performed in a Veritti ${ }^{\circledR}$ (Applied Biosystems) thermocycler. The cycling parameters used were: an initial denaturation at $95^{\circ} \mathrm{C}$ for $5 \mathrm{~min}$, followed by 35 cycles of $95^{\circ} \mathrm{C}$ for $30 \mathrm{~s}, 55^{\circ} \mathrm{C}$ for $30 \mathrm{~s}$, and $72^{\circ} \mathrm{C}$ for $30 \mathrm{~s}$, with a final elongation cycle of $72{ }^{\circ} \mathrm{C}$ for $5 \mathrm{~min}$. The PCR products were evaluated in a $1 \%$ agarose gel electrophoresis (1x SB) stained with ethidium bromide. The plants identified 
as positive were used in experiments for molecular, physiological and agronomical evaluations.

\section{Segregation pattern analysis and copy number quantification of the transgene via qPCR}

The segregation pattern in the generated events was analyzed through conventional PCR, in plants from T1 and T2 generations. The $\mathrm{X}^{2}$ test $(p \leq 0.05)$ was applied to check if AtNCED3 gene was segregating in agreement with the expected Mendelian pattern.

Transgene-inserted copy number quantification was achieved using AtNCED3 as the target gene and Lec gene (GmLec, Accession No. K00821), as endogenous and calibrator. This is a soybean species-specific gene that presents only one copy in the haploid genome (Meyer et al., 1994), or two allelic copies (homozygous).

An amplification efficiency curve was performed, for both target and calibrator genes, using a series of DNA dilutions $\left(5^{-6}, 5^{-5}, 5^{-4}, 5^{-3}\right.$ and $\left.5^{-2}\right)$. The amplification reactions were composed of DNA dilutions (one reaction for each dilution), $0.2 \mu \mathrm{MF}$ and $\mathrm{R}$ primers (Table $\mathrm{S} 1 \mathrm{~B}$ ), and $1 \mathrm{x}$ reaction buffer Platinum $^{\circledR}$ SYBR Green ${ }^{\circledR}$ qPCR SuperMix UDG (Invitrogen) composed of Taq DNA polymerase, Tris- $\mathrm{HCl}$, $\mathrm{KCl}, 6 \mathrm{mM} \mathrm{MgCl} 2,400 \mu \mathrm{M}$ dGTP, $400 \mu \mathrm{M}$ dATP, $400 \mu \mathrm{M}$ $\mathrm{dCTP}, 800 \mu \mathrm{M}$ dUTP, uracil DNA glycosylase (UDG), and stabilizers. Reactions were carried out in three biological and technical replicates in a 7900HT (Applied Biosystems) thermocycler. The cycling parameters used were: $50{ }^{\circ} \mathrm{C}$ for 2 min, denaturation at $95^{\circ} \mathrm{C}$ for $10 \mathrm{~min}$, followed by 40 cycles of $95{ }^{\circ} \mathrm{C}$ for $15 \mathrm{~s}, 60{ }^{\circ} \mathrm{C}$ for $1 \mathrm{~min}, 95^{\circ} \mathrm{C}$ for $15 \mathrm{~s}, 60^{\circ} \mathrm{C}$ for $15 \mathrm{~s}$, and $95^{\circ} \mathrm{C}$ for $15 \mathrm{~s}$.

The PCR reaction efficiency was calculated using the $\mathrm{E}=[5-1 /$ slope $]-1$ formula (Pfaffl, 2001). AtNCED3 gene inserted copy number was quantified by subtracting $\mathrm{Ct}$ values of the target gene from the $\mathrm{Ct}$ value of the endogenous reference gene (GmLec, Accession No. K00821), resulting in the $\Delta \mathrm{Ct}$ value for each sample. The copy number was calculated as 2 elevated to the average of $-\Delta \mathrm{Ct}{ }^{(2-\Delta \mathrm{Ct})}$, where 2 corresponds to the sum of the target gene $(100 \%=1)$ and the endogenous control $(100 \%=1)$ efficiencies, and it differs depending on primer efficiency in the amplification reaction (Livak and Schmittgen, 2001).

\section{Analysis of gene expression by RT-qPCR}

The total RNA was extracted from soybean leaf samples using Trizol ${ }^{\circledR}$ reagent. After that, samples were treated with DNase I kit (Invitrogen, Carlsbad, CA) to remove possible remaining DNA and lastly the cDNA was synthesized using SuperScript ${ }^{\circledR}$ III First-Strand Synthesis System (Invitrogen/ Catalog number: 180800) according to the manufacturer's instructions. The relative gene expression quantification was carried out in three biological and technical replicates $(n=9)$. Reactions were composed of cDNAs, $0.2 \mu \mathrm{M} F$ and $\mathrm{R}$ primers and $1 \mathrm{x}$ reaction buffer Platinum ${ }^{\circledR}$ SYBR Green ${ }^{\circledR}$ qPCR SuperMix UDG (Invitrogen). The reactions were conducted in a 7900HT thermocycler (Applied
Biosystems), following the same cycling conditions described above.

The sequences used to design primers for RT-qPCR were obtained from Phytozome. The CDS sequence from the AtNCED3 gene from plasmid was aligned with soybean endogenous genes GmNCED3 (Glyma.05G140900.1 and Glyma.08G096200.1) using CLUSTWAL W. A set of primers was designed to amplify a genomic region specific from Arabidopsis thaliana, ensuring that any differences in gene expression and copy number quantification did not result from the expression of the endogenous gene GmNCED3.

The expression level of ABA-dependent genes, such as GmAREB1 (Glyma.04G039300; Glyma.07G213100; Glyma.02G131700), GmPP2C (Glyma.14G195200), GmSnRK2 (Glyma.02G135500), and GmAAO3 (Glyma.14gG045100) was quantified. The GmAREBl genes were aligned and primers designed in a conserved region. Specific primers for the endogenous genes GmPP2C, $G m S n R K 2$ and GmAAO3 were also designed using the Primer3Plus software (Table S1C).

The gene expression relative quantification was carried out in three biological and technical replicates $(n=9)$. The reactions were comprised of cDNAs, $0.2 \mu \mathrm{M} \mathrm{F}$ and $\mathrm{R}$ primers and $1 \mathrm{x}$ reaction buffer Platinum ${ }^{\circledR}$ SYBR Green ${ }^{\circledR}$ qPCR SuperMix UDG (Invitrogen). Reactions were conducted in a 7900HT thermocycler (Applied Biosystems), following the same cycling conditions described above. The gene expression level was determined using the formula $2^{-\Delta \Delta c t}$ (Rodrigues et al., 2015). Statistical analysis was carried out by applying the $t$-test $(p \leq 0.05)$.

Considering segregation and transgene quantification results, the event AtNCED3 $2 \mathrm{Ha} 11$ was chosen to be evaluated regarding growth, physiological and agronomical traits in experiments carried out under greenhouse and field conditions.

\section{Evaluation of GM event submitted to WD under greenhouse conditions}

T2 generation seeds from AtNCED3 $2 \mathrm{Ha} 11$ event and BRS 184 soybean conventional cultivar (WT plants) were treated with $\operatorname{Vitavax}^{\circledR}$ Thiram 200 SC $\left(200 \mathrm{~g}^{-1}\right)$ (ADAPAR) for health quality purposes. After that, the seeds were germinated on Germitest ${ }^{\circledR}$ paper, for $96 \mathrm{~h}$ at $25 \pm 1{ }^{\circ} \mathrm{C}$ and $100 \%$ relative humidity $(\mathrm{RH})$. Then, seedlings were relocated to 11 pots filled with substrate mixture (soil-sandorganic compound $3: 2: 2$ ), each pot containing one seedling. The pots with seedlings were maintained in a greenhouse at $28 \pm 2{ }^{\circ} \mathrm{C}$, with records of temperature and $\mathrm{RH}$ (relative humidity) every 5 min through a thermohygrograph (Hobo U14-002, Onset ${ }^{\circledR}$ ). Experimental design was in completely randomized blocks, in a $2 \times 2$ factorial arrangement, i.e. two plant materials (2Ha11 and BRS 184) and two water conditions (control - C and water deficit - WD), with nine blocks.

A conventional PCR using primers specific for the transgene was carried out when plants reached V1 developmental stage (Fehr et al., 1971). The plants were kept at $100 \%$ field capacity (FC) until phenological stage V4, by ir- 
rigating them with a fixed volume of water sufficient to saturate the substrate. At V4 stage, one day before WD treatment, at the end of the afternoon, all pots were saturated with water and excess water drained overnight. In the following morning, the pots were giftwrapped in polyethylene bags and the central region of each pot was covered with cotton around the stem base to prevent water loss by evaporation. Control plants group were maintained at 100\% FC, while in the WD group irrigation was withheld. Stomatal conductance $(g s)$ was monitored daily. When WD-group plants presented $g s$ values less than $200 \mathrm{mmol} \mathrm{H}_{2} \mathrm{O} \mathrm{m}^{-2} \mathrm{~s}^{-1}$ (Flexas et al., 2004; Salinet, 2009) which occurred eight days after withholding irrigation, gas exchange parameters photosynthetic rate $(A)$, sub-stomatal $\mathrm{CO}_{2}(C i)$, transpiration rate $(E)$, and $g s$ - were measured, using a portable infrared gas analyzer (LCpro-SD, ADC BioScientific). The measurements were carried out inside the greenhouse from $9.00 \mathrm{am}$ (Brazilian daylight-saving time) at $1000 \mu \mathrm{mol} \mathrm{m} \mathrm{m}^{-2} \mathrm{~s}^{-1}$ photosynthetically active radiation (PAR), on the central leaflet of the third fully-expanded trifoliate leaf (apex-base direction) in three different plants. The intrinsic water use efficiency (WUE) was achieved through the ratio $A / g s$. Afterward, the same trifoliate leaf was collected, wrapped in aluminum foil, immersed in liquid nitrogen and stored at $-80^{\circ} \mathrm{C}$. These biological materials were used to perform gene expression analysis, by RT-qPCR.

Seven days after withholding irrigation, the number of nodes $(\mathrm{NN})$ and the total leaf area were assayed, using a leaf area meter (LI-3100C model, Licor). Leaf blades, stems, petioles and roots were dried to constant weight, in a forced aeration oven at $60^{\circ} \mathrm{C}$, to weight shoot dry matter (leaf blades + stems + petioles) and root dry matter (per plant). The plant height was measured in two points: at the start (H1) and at the end (H2) of WD-treatment period. The mean length of internodes corresponded to the ratio between $\mathrm{H} 2$ and the number of nodes. The relative growth rate in height (RGRH) was estimated using RGRH $(\%)=[((\mathrm{H} 2-\mathrm{H} 1) / \mathrm{H} 1) \times 100]$ equation.

After the evaluation of growth parameters and sampling for gene expression analysis, the plants were moved to 81 pots filled with a substrate composed of soil-sand-organic compound $(3: 2: 2)$. All pots were maintained under continuous irrigation until the end of the cycle, when agronomical traits (per plant) such as number of seeds, number of pods presenting seeds, total number of seeds, and yield were evaluated.

\section{Evaluation of GM events submitted to WD-treatment in field conditions}

The experiment was conducted during the crop seasons 2015/16 and 2016/2017, in a field area located at Na-

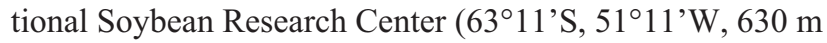
altitude) a Brazilian Agricultural Research Corporation (Embrapa Soybean, Londrina, PR, Brazil) unit. All required documentation to test the GM lines in field conditions was submitted to and approved by CTNBio (Process $n^{\circ}$
01200.002859/2015-54 published in the Brazilian Official Journal on August 10, 2015, Technical advice \#4.648/2015).

A randomized complete block split-plot design was applied, with four blocks. The plots corresponded to two water treatments: irrigated (IRR: water from rainfall + irrigation applied when soil matric potential reached values between -0.03 and $-0.05 \mathrm{MPa}$ ) and non-irrigated (NIRR: water from rainfall). The subplots corresponded to the BRS 184 soybean conventional cultivar and its isoline, the transgenic event AtNCED3 2Ha11. Each subplot corresponded to 220 $\mathrm{m}^{2}$.

The cultivation practices during the experiment followed procedures routinely approved at Embrapa Soja (Embrapa, 2011). BRS 360RR cultivar soybean plants were used as a $10 \mathrm{~m}$ isolation border, according to the Brazilian legislation. RH and air temperature were daily monitored through a weather station located near to the experiment area. Plants were evaluated for number and dry matter of seeds, pods with seeds, 100-seed weight and yield at the end of the cycle. The sequential water balance was assayed according to Thornthwaite and Mather (1955).

\section{ABA quantification}

For the ABA quantification, an experiment was performed in greenhouse conditions following the same procedures previously described. However, WD imposition was maintained for 10 days. Thus, leaf samples $(1 \mathrm{~g})$ from the 2Ha11 GM line and BRS 184 soybean conventional cultivar were collected, submerged in liquid nitrogen and warehoused at $-80^{\circ} \mathrm{C}$. An aliquot $(1 \mathrm{mg})$ of leaf tissue was powdered in a $1.5 \mathrm{ml}$ microtube containing metal beads and 500 $\mu \mathrm{L}$ extraction buffer was added (80\% methanol, $0.5 \mathrm{~g} \mathrm{~L}^{-1}$ monohydrate citric acid, $100 \mathrm{mg} \mathrm{L}^{-1}$ butyl hydroxytoluene). The solution was maintained overnight, at $-4{ }^{\circ} \mathrm{C}$. The next day, the solution was centrifuged for $10 \mathrm{~min}$, at $4{ }^{\circ} \mathrm{C}$, at $6,000 \mathrm{~g}$ and the pellet resuspended in $500 \mu \mathrm{L}$ TBS buffer $(45$ mm Tris-HCl, pH 7.8; $90 \mu \mathrm{M} \mathrm{MgCl}_{2}, 0.135 \mathrm{M} \mathrm{NaCl}, 10 \%$ methanol). The ABA concentration was quantified using Phytodetek immunoassay kit (ABA Agdia Inc.), following to the manufacturer's instructions.

\section{Statistical analysis}

Data displayed normal distribution and were submitted to analysis of variance (ANOVA) and comparison of means by Tukey test $(p \leq 0.05)$. The gas exchange parameters were compared between plant materials (BRS 184 soybean conventional cultivar and 2Ha11GM line) and between water treatments (C- control and WD-water deficit). Plant height, leaf area, number of seeds per plant, 100-seed weight, yield and total number of pods were compared between the plant materials (BRS 184 soybean conventional cultivar and 2Ha11GM line) and between crop seasons (2015/2016 and 2016/2017). 


\section{Results}

Identification of GM plants positive to 35S:AtNCED3, segregation pattern analysis and copy number quantification of the transgene via qPCR

One hundred and eighty-four cotyledons from BRS 184 soybean conventional cultivar were transformed with the construct 35S:AtNCED3, through the Agrobacterium tumefaciens method. Two positive events were identified in $\mathrm{T} 0$ generation and named $2 \mathrm{Ha} 1 \mathrm{l}$ and $2 \mathrm{Ha} 13$, with a transformation efficiency of $1.08 \%$. This efficiency was calculated by dividing the number of positive plants per total number of explants transformed $\times 100$. In T1 generation, seven plants were identified as positive - five from the event $2 \mathrm{Ha} 11$ and two from the event $2 \mathrm{Ha} 13$.

The segregation pattern analysis and the copy number quantification of the transgene via $\mathrm{qPCR}$ were carried out in plants from T2 generation. The event $2 \mathrm{Ha} 11$ followed the Mendelian segregation pattern, but the event $2 \mathrm{Ha} 13$ did not (Table 1). Although a second GM line was obtained and initially characterized, the transgene in line $2 \mathrm{Ha} 13$ was an instable insertion, not being transferred to further generations than $\mathrm{F}_{1}$; thus, it was discarded from further analysis.

The results from qPCR showed that the GM event $2 \mathrm{Ha} 11$ presented from one to four copies of the transgene, randomly inserted in the soybean genome.

\section{Analysis of gene expression by RT-qPCR}

The higher expression levels were detected for all analyzed genes in the event 2Ha11 when compared to WT-plants, in WD conditions. The transgene AtNCED3 presented 2.4 times higher expression in the $2 \mathrm{Ha} 11$ event when compared to its genetic background BRS 184, which showed no expression to the transgene. The endogenous genes GmAREB1 (Glyma.04G039300; Glyma.07G213100; Glyma.02G131700), GmPP2C (Glyma.14G195200), GmSnRK2 (Glyma.02G135500), and GmAAO3 (Glyma.14gG045100) showed respectively 3.7, 3.9, 1.4, and 7.4 times higher expression in the GM event when compared to BRS 184 plants (Figure 1).

\section{Growth, physiological and agronomical traits under greenhouse and field conditions for two crop seasons}

The gas exchange measurements $\left(g_{s}, \mathrm{Ci}, \mathrm{A}, \mathrm{E}\right)$ evaluated in the greenhouse did not show statistical differences

Table 1 - Chi-square $\left(\mathrm{X}^{2}\right)$ test for Mendelian segregation pattern, in $\mathrm{T}_{2}$ generation, for 35S:AtNCED3 construction. $(\mathrm{p} \leq 0.05)$. Y: Yes. N: No.

\begin{tabular}{lccccc}
\hline Events $\mathrm{T}_{1}$ & $\begin{array}{c}\text { Total/ } \\
\text { seeds }\end{array}$ & $\begin{array}{c}\text { Positive } \\
\text { plants }\end{array}$ & $\begin{array}{c}\text { Negative } \\
\text { plants }\end{array}$ & $\mathrm{X}^{2}$ & $\begin{array}{c}\text { Segregation } \\
(3: 1)\end{array}$ \\
\hline 2Ha 11-2 & 119 & 95 & 24 & 1,48 & $\mathrm{Y}$ \\
2Ha 11-3 & 95 & 71 & 24 & 0 & $\mathrm{Y}$ \\
2Ha 11-4 & 239 & 182 & 57 & 0,18 & $\mathrm{Y}$ \\
2Ha 11-5 & 6 & 5 & 1 & 0,06 & $\mathrm{Y}$ \\
2Ha 11-6 & 30 & 22 & 8 & 0,01 & $\mathrm{Y}$ \\
2Ha 13-51 & 291 & - & 291 & - & $\mathrm{N}$ \\
2Ha 13-52 & 47 & - & 47 & - & $\mathrm{N}$ \\
\hline
\end{tabular}

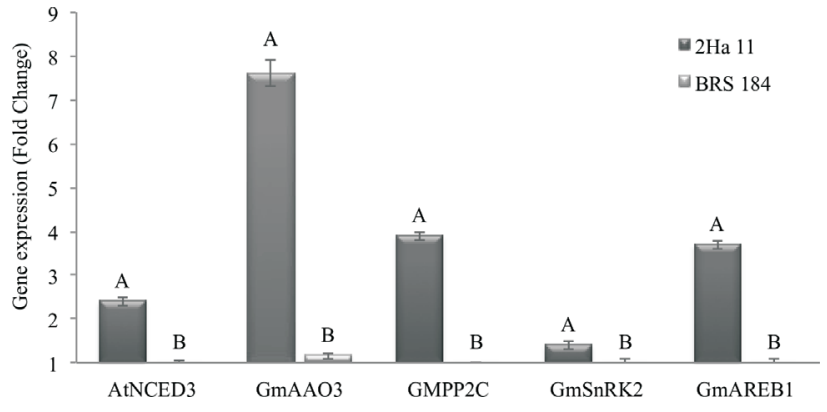

Figure 1 - Quantification of relative expression of transgene AtNCED3 and endogenous genes GmAREB1 (Glyma.04G039300; Glyma07.G213100; Glyma.02G131700), GmPP2C (Glyma.14G195200), GmSnRK2 (Glyma.02G135500) and GmAAO3 (Glyma.14G045100) in the GM event $2 \mathrm{Ha} 11$ and conventional cultivar BRS 184 (genetic background). Reactions were carried out in three biological and three technical replicates. Bars represents standard error.

between the GM event 2Ha11 and WT plants, under irrigated conditions. However, under WD, these parameters decreased in the event 2Ha11 (Figure 2A-D). Furthermore, the transgenic plants showed $80 \%$ higher intrinsic water use efficiency $\left(A / g_{s}\right)$ when compared to WT plants, under WD (Figure 2E). No differences were observed for number of nodes $(\mathrm{NN})$, shoot dry matter, root dry matter, mean length of internodes and relative growth rate in height.

In field conditions, no significant interaction between plant materials and water conditions was observed; probably due to the great amount of rainfall recorded during both crop seasons. The results from field experiments (crop seasons 2015/16 and 2016/17) presented in figures comprise average values from both water conditions (irrigated and non-irrigated treatments), for each cultivar/GM line. The data collected at the weather station showed that the total rainfall recorded was 1,521.4 $\mathrm{mm}$ (Figure S2A) and 1,147.2 $\mathrm{mm}$ (Figure S2B), respectively, in the 2015/16 and 2016/17 crop-seasons. These volumes were higher than the recommendations for soybean crop, which ranges from 450 to 800 $\mathrm{mm} /$ cycle, depending on crop management, general weather conditions and cycle duration (Embrapa, 2014).

In greenhouse and field conditions, the $2 \mathrm{Ha} 11 \mathrm{GM}$ line presented similar responses for height, showing on average $12 \mathrm{~cm}$ less in greenhouse (data not shown) and 8-9 cm less in field experiments when compared to WT plants (Figure 3A).

When crop seasons were compared, the GM event 2Ha11 presented lower height (Figure 3A), lower leaf area (Figure 3B), lower number of seeds per plant (Figure 3C), higher 100-seed weight (Figure 4A) although not statically different, and higher yield (Figure 4B) in the crop season 2015/16 than in 2016/17. In the 2015/2016-crop season, the GM event $2 \mathrm{Ha} 11$ also showed higher total number of pods (Figure 5A) and yield when compared to the WT plants (Figure 4B).

\section{ABA quantification in soybean plants submitted to WD in greenhouse}

The ABA quantification was performed in GM and WT plants under control and WD (10 days of withholding ir- 

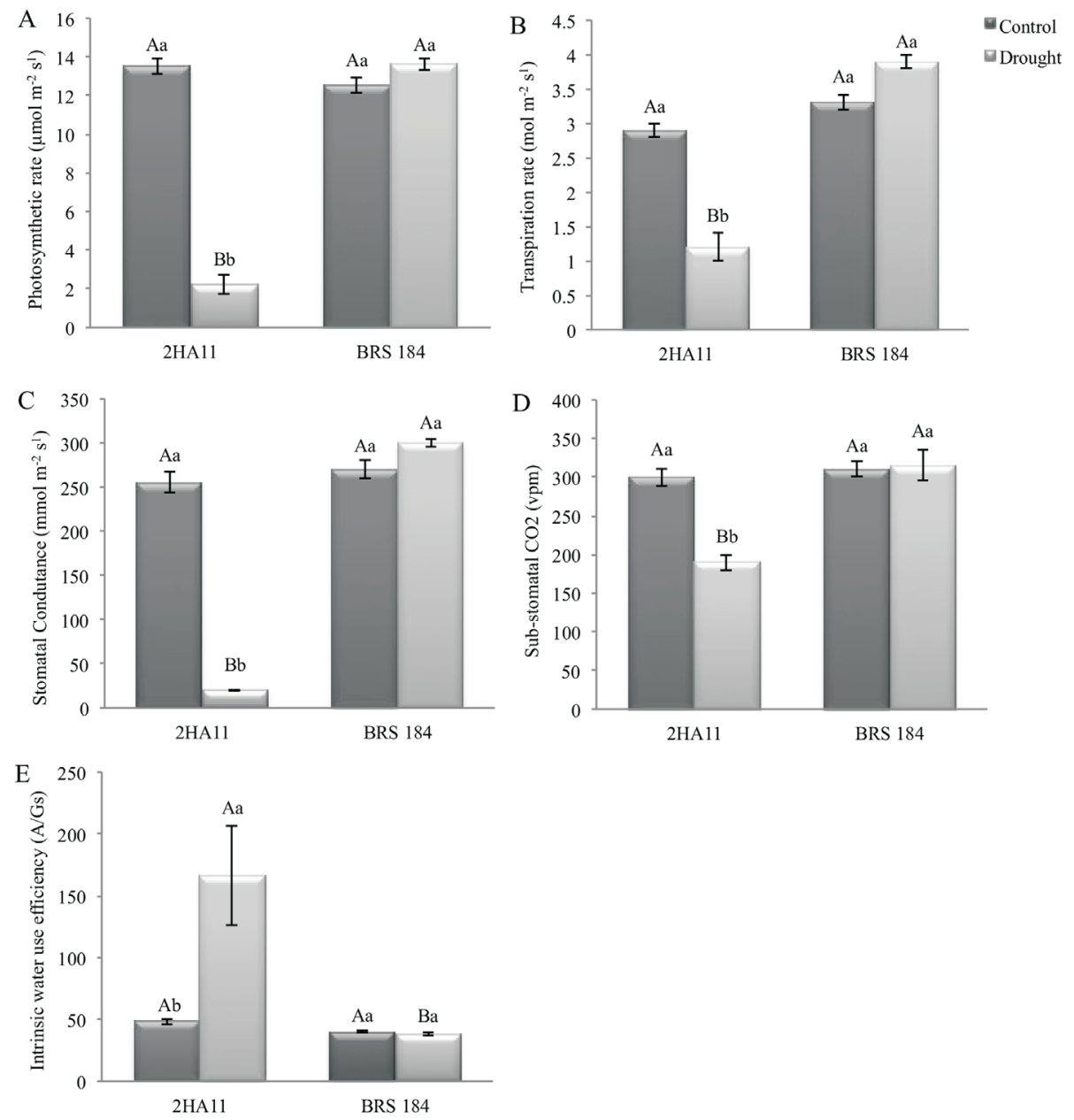

Figure 2 - Gas exchange measurements and intrinsic water use efficiency in the conventional soybean cultivar BRS 184 and its isoline, the transgene $2 \mathrm{Ha} 11$ AtNCED3, under water deficit induced in greenhouse conditions. Means \pm standard error of nine replicates. The means followed by the same letters do not differ by the Duncan test $(p \leq 0.05)$. The uppercase letters compare GM line and conventional cultivar (2Ha11/BRS184) and the lowercase letters compare water conditions (control/drought).

rigation) conditions. Obtained data were analyzed statistically by Tukey test $(p \leq 0.05)$. Plants from the event $2 \mathrm{Ha} 11$ under WD showed an ABA concentration of 166.34 pmol $\mathrm{mL}^{-1}$, while BRS 184 plants under WD and both plant materials under control conditions showed ABA concentrations under 4 pmol $\mathrm{mL}^{-1}$, which is the minimum limit detected by the kit.

\section{Discussion}

Among the climatic problems that agriculture has currently faced, drought has mostly affected yield and the economy of producing regions. The solutions to cope with and minimize this environmental stress are urgently needed to maintain suitable levels of productivity and to feed the worldwide growing and starving population in the next decades. Therefore, GM soybean plants containing the AtNCED3 gene were obtained. The NCED3 gene encodes for a vital enzyme in the ABA biosynthesis pathway. Briefly, the zeaXanthin epoxidase (ZEP, EC: 1.14.13.90, Zea-epoxidase) (Marin et al., 1996) catalyzes the epoxidation of
zeaXanthin to produce epoxycarotenoid; 9-cis-epoxycarotenoid dioxygenase (NCED) (Schwartz et al., 1997). The NCED enzyme catalyzes the cleavage reaction of epoxycarotenoid to produce xanthoxin (the first C15 intermediate); and abscisic aldehyde oxidase (AAO, EC: 1.2.3.14) (Seo et al., 2000), which catalyzes the final step, converting ABA aldehyde to ABA. The xanthophyll cleavage by NCED is rate limiting and the first committed stage in ABA biosynthesis (Nambara and Marion-Poll, 2005).

In general, genetic transformation through A tumefaciens methodology inserts a low number of transgene copies into host genome, reflecting in a Mendelian segregation in T2 generation (Oltmanns et al., 2010), as identified for the event $2 \mathrm{Ha} 1 \mathrm{1}$. However, the GM event $2 \mathrm{Ha} 13$, obtained independently did not present Mendelian segregation, suggesting a high number of transgene copies inserted. The GMs lines obtained through this methodology are independently events and usually behave differentially, once the transgene is randomized inserted into the genome which can confer instability to the transgene (Dominguez et al., 2002), not being 

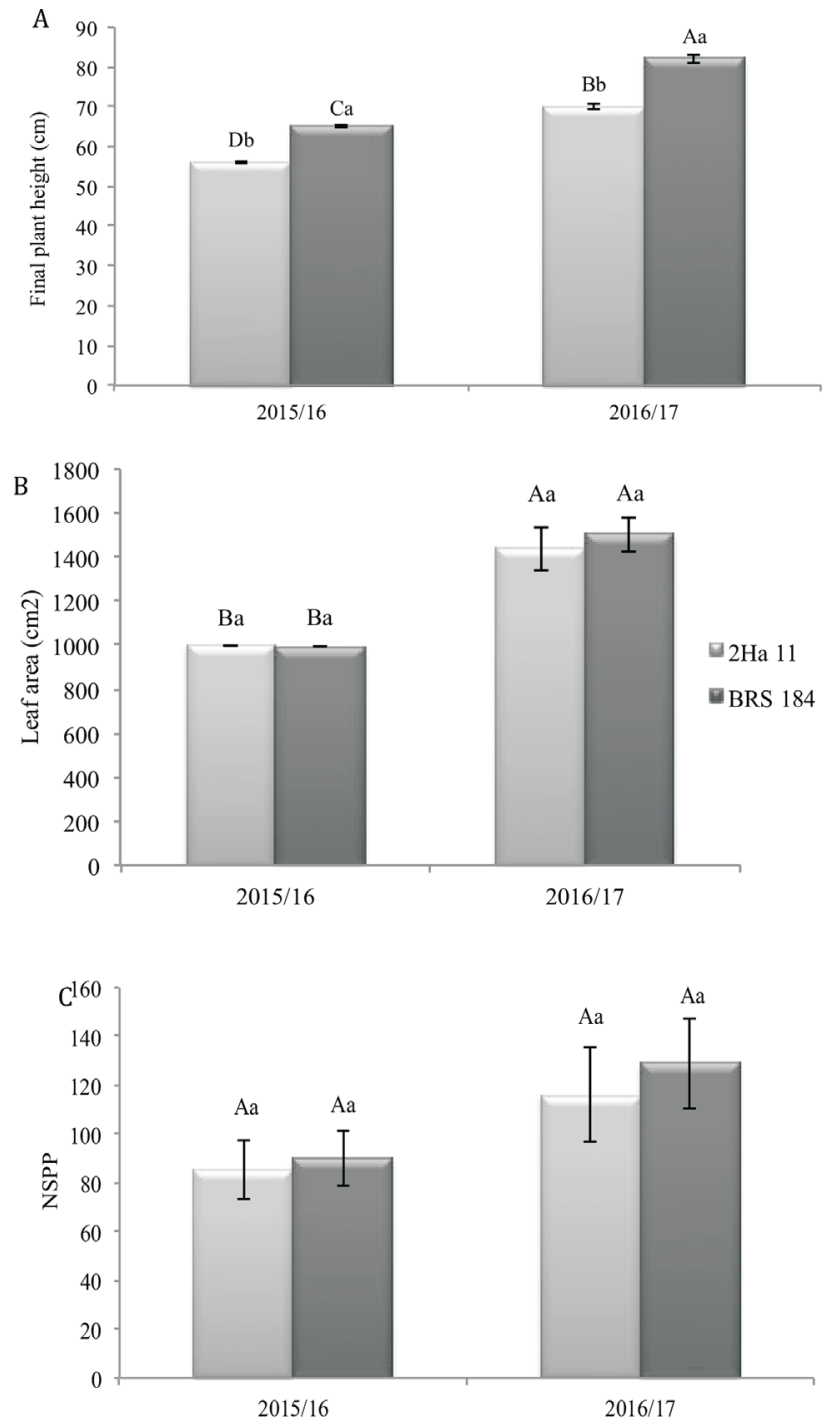

Figure 3 - Pllant height, leaf area and number of seeds per plant (NSPP) in the conventional soybean cultivar BRS 184 and its isoline, the transgene 2Ha11 AtNCED3, under water deficit induced in field conditions for two crop seasons. Means \pm standard error of six replicates. The means followed by the same letters do not differ by the Duncan test $(p \leq 0.05)$. The uppercase letters compare crop seasons (2015/16 and 2016/17) and the lowercase letters compare GM line and conventional cultivar (2Ha11/BRS184).

transmitted to further generations as occurred with $2 \mathrm{Ha} 3$ line.

Although soybean is considered as recalcitrant for plant transformation, our research group had already reported soybean GM events presenting a low copy number of transgenes (as 2Ha11 line) regardless of the construct (Marinho et al., 2015; Honna et al., 2016). This characteristic is desired when GM lines are incorporated into breeding programs, as it implies in an easier fixation by self-pollination and facilitates the transgene identification in further crosses to develop cultivars more tolerant to drought. Likewise, the expression of the transgene is mandatory. Thus, in the present study, the GM event $2 \mathrm{Ha} 11$ showed higher expression
A

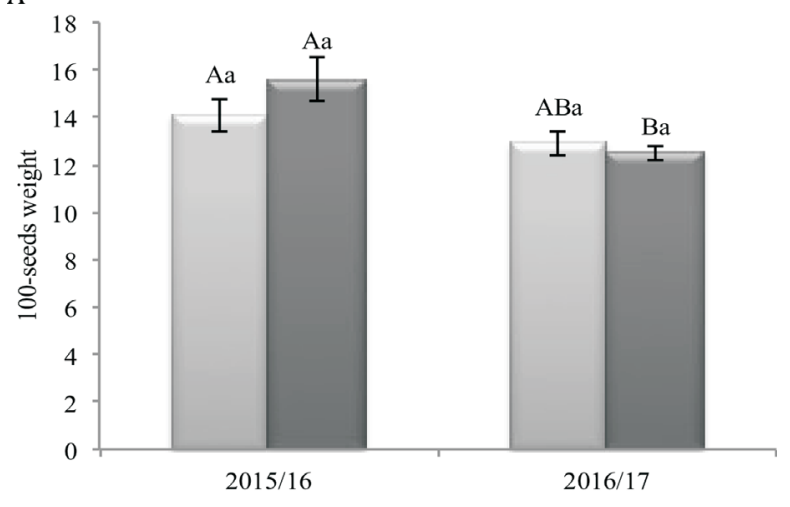

$\nabla_{2 \mathrm{Ha}} 11$

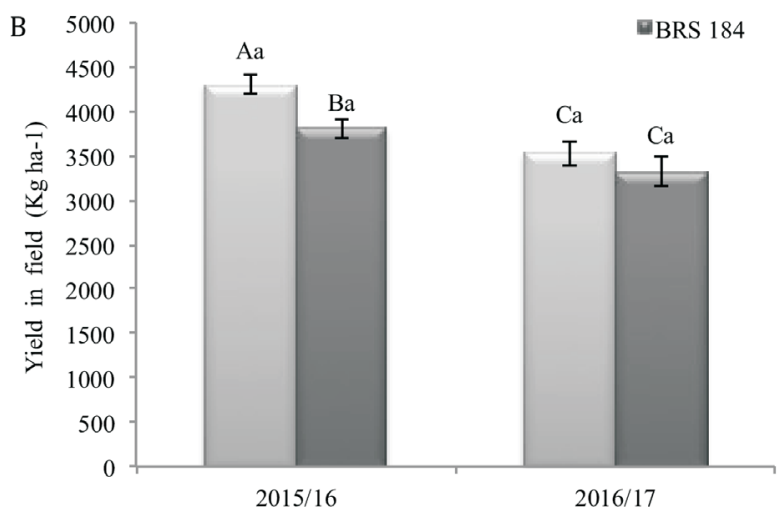

Figure 4 - Data from 100-seed weight and yield in the conventional soybean cultivar BRS 184 and its isoline, the transgene 2Ha11 AtNCED3, under water deficit induced in field conditions for two crop seasons. Means \pm standard error of six replicates. The means followed by the same letters do not differ by the Duncan test $(p \leq 0.05)$. The uppercase letters compare crop seasons (2015/16 and 2016/17) and the lowercase letters compare GM line and conventional cultivar (2Ha11/BRS184).

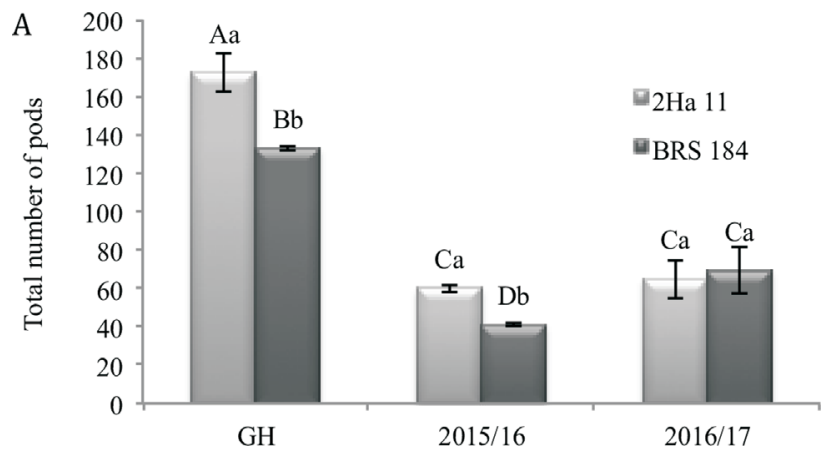

Figure 5 - Total number of pods in the conventional soybean cultivar BRS 184 and its isoline, the transgene 2Ha11 AtNCED3, under water deficit induced in field conditions for two crop seasons. Means \pm standard error of six replicates. The means followed by the same letters do not differ by the Duncan test $(p \leq 0.05)$. The uppercase letters compare results from $\mathrm{GH}$ (greenhouse) and crop seasons (2015/16 and 2016/17) and the lowercase letters compare GM line and conventional cultivar (2Ha11/BRS184).

levels (6 times more than control condition) of AtNCED3 and the endogenous genes GmAREB1, GmPP2C, $G m S n R K 2$, and GmAAO3 under WD (Figure 1), suggesting that NCED gene is involved in drought response in soy- 
beans. This expression level was also reported for Arabidopsis (Chan, 2012). According to this author, the levels of NCED gene can range from -3 to 3 (respectively, down- and up-regulation) in drought condition, similar to what was obtained in soybean, and vary with the time of induction of the stress, being enough to induce drought-responses in the plants. Furthermore, the ABA synthesis pathway was triggered in response to WD in GM event $2 \mathrm{Ha} 11$, as observed by higher ABA levels detected under such a condition in the GM plants.

As reported here, in Arabidopsis, the overexpression of AtNCED3 also directed an increase in ABA endogenous levels and induced ABA-genes. Furthermore, Arabidopsis plants overexpressing AtNCED3 presented an improvement in drought tolerance (Iuchi et al., 2001). The participation of NCED genes in drought tolerance was also reported in other plant species. Under WD, plants of Caragana korshinskii, displayed ABA accumulation in leaves and stems, followed by a significant increase in CkNCED1 mRNA levels (Wang et al., 2009). Furthermore, in Stylosanthes guianensis, SgNCED1 gene expression was induced in leaves and roots submitted to drought-conditions. Dehydration also strongly and rapidly induced the expression of SgNCED1, and the ABA accumulation was coincidently detected with an increase in $S g N C E D 1$ mRNA levels under stress (Yang and Guo, 2007). Moreover, tobacco overexpressing the SgNCED1 gene showed enhanced drought tolerance, with induced-expression of drought-responsive genes (Bao et al., 2016). These responses were also described to important economic crops, which in some cases was accompanied by a significant increase in the ABA levels, as observed here for soybean. In dehydrated leaves of saffron (Crocus sativus), increased levels of CstNCED mRNA were detected $2 \mathrm{~h}$ after detachment, reaching its highest level after 5h (Ahrazem et al., 2012). In avocado (Persea americana Mill. cv Lula), $P A N C E D 1$ gene expression was significantly increased by $80 \%$ in dehydrated leaves (Chernys and Zeevaart, 2000). In common beans (Phaseolous vulgaris), preceding the accumulation of ABA, mRNA and protein levels of PvNCED1 gene were strongly induced in response to water stress (Quin and Zeevaart, 1999). Furthermore, plants of transgenic tobacco (Nicotiana plumbaginifolia Viv.) overexpressing PvNCED1 gene showed higher ABA levels (Marin and Quesada, 1996). Moreover, cowpea (Vigna unguiculata) plants showed accumulation of $\mathrm{ABA}$ and expression of $V u N C E D 1$ was strongly induced by water deficit. As reported here in soybean, a high ABA concentration under WD was also identified in Arabidopsis plants 10h-dehydrated, which showed 140 times higher ABA levels than unstressed plants (Iuchi et al., 2000).

Furthermore, in leaves and stems of peanut (Arachis hypogaea L.), higher levels of ABA were also reported after 15 days of withholding irrigation, as well as a significant up-regulation of AhNCEDI under dehydration conditions (Wan and Li, 2006). In citrus (Citrus sinensis L. Osbeck), CsNCED1 gene expression increased in water-deficit treated leaves, in a consistent pattern with ABA accumulation (Ro- drigo et al., 2006). Also, in Clemenules mandarin (Citrus clementina), during the water scarcity/re-watering rounds, $C C N C E D 3$ gene expression paralleled the pattern of ABA accumulation in leaves (Agustí et al., 2007). In 'Rangpur' lime, the NCED5 gene was highly induced in leaves. Furthermore, in 'Sunki Maravilha', NCED2 gene was also highly expressed in leaves. In both genotypes, the transcription levels of these genes correlated with ABA accumulation in severe WD conditions (Marin et al., 1996). In tomato, an increase in LeNCED mRNA levels was reported during drought conditions (Thompson et al., 2000). In soybean, GmNCED3, GmNCED4 and GmNCED5 genes higher expression was also reported and showed to be limited by light under treatment conditions, the period in which stomatal closure is required to prevent water loss by evapotranspiration (Rodrigues et al., 2015). As observed in the present study, all these reports corroborate the strong and direct relationship among the expression of NCED genes, increased ABA levels and the activation of drought responses, such as stomatal closure, to reduce water loss under WD.

Likewise, as reported in this work for soybean, higher expression of the drought-responsive endogenous genes GmAREB1, GmPP2C, GmSnRK2, and GmAAO3 was also reported in Arabidopsis genetically modified with AtNCED3 (Iuchi et al., 2001). Considering genes from the ABA pathway, an increase in aldehyde oxidase genes under WD was reported in Arabidopsis (Koiwai et al., 2004), pea (ZdunekZastocka and Sobczak, 2013) and peanut (Yang et al., 2011). In $A$. thaliana, $A A O 3$ transcripts presented a strong increase in response to water deficit (Koiwai et al., 2004). In Arachis hypogaea L., a dominant expression of the AhAO2 gene was observed in leaves. The overexpression of AhAO2 in Arabidopsis headed to an increase in ABA levels and improved drought tolerance (Yang et al., 2011). In pea (Pisum sativum), during a progressively induced drought treatment, levels of PSAO3 transcripts increased expressively in roots and leaves, while ABA accumulation was identified only in leaves, complemented by the induction of the PSNCED3 gene expression (Zdunek-Zastocka and Sobczak, 2013).

The high expression of GmPP2C and GmSnRK2 genes identified in the present study reflects the refined control of ABA synthesis, which is negatively regulated when the ABA levels exceeded, by the inhibition of NCED enzyme, preventing that high hormone levels implies in plant metabolic disturbances (Liu et al., 2016). The initial events in the ABA signaling pathway strike through a central signaling module comprising three classes of proteins: the ABA receptors - PYR/RCARs; the negative regulators - protein phosphatase 2Cs (PP2Cs); and the positive regulators of downstream signaling - SNF1-related protein kinase 2s (SnRK2s) (Ma et al., 2009; Park et al., 2009). A double-negative regulatory pathway is established, whereby ABA-bound PYR/RCARs inhibit PP2C activity and PP2Cs inactivate SnRK2s (Park et al., 2009; Umezawa et al., 2009; Vlad et al., 2009). Therefore, in ABA absence, PP2Cs are active and repress SnRK2 activity. In ABA presence, PYR/RCARs interact with PP2Cs and inhibit phosphatase activity, leading 
to SnRK2 activation and phosphorylation of target proteins (Hubbard et al., 2010). In land plants, ABA receptors SnRK2, group A PP2Cs, and RCAR/PYR/PYL control ABA signaling pathway including TFs AREB/ABFs Umezawa, Nakashima and Miyakawa, 2010; Nakashima and Yamaguchi-Shinozaki, 2013 and Miyakawa et al., 2013). Thus, SnRK2s phosphorylate ABFs (ABRE-binding factors), conserved ABA-responsive cis-elements (ABRE) present in the promoter region of genes ABA-regulated (Furihata et al., 2006), such as ZIP TFs, AREB1/ABF2, AREB2/ABF4 and ABF3 (Yoshida et al., 2014). Therefore, in soybean, $G m S n R K 2$ might have activated the expression of GmAREB 1 by phosphorylation.

Data from physiological characterization of AtNCED3 soybean lines showed that the level of transgene expression detected was able to induce endogenous ABA levels, resulting in plants with more water use efficiency and therefore, performing better not only under greenhouse experiments but also under field conditions. According to the available literature, plants facing low to moderate water deficit will frequently enhance WUE (Brock and Galen, 2005; Liu et al., 2005; Yin et al., 2005; Medrano et al., 2015), maybe as a protective mechanism against stress, by allowing plants to save water and improve its use efficiency (Chaves et al., 2009), mainly with the objective to convert available $\mathrm{CO}_{2}$ into photoassimilates in pods and in grain production, and thus reflecting in increased in yield.

The decrease in gas exchange parameters observed in the soybean GM event $2 \mathrm{Ha} 11$ under WD has also been described in other plants species. Arabidopsis overexpressing AtNCED3 gene (Iuchi et al., 2001) and OsNCED3 gene from rice (Hwang et al., 2010) showed a decrease in the transpiration rate in leaves. Furthermore, genetically modified tobacco lines overexpressing $S g N C E D 1$ also showed higher ABA levels, a decrease in transpiration rate and lower photosynthetic rate (24-47\%), as a result of lower stomatal conductance (Zhang et al., 2008). Detached leaves from transgenic tobacco overexpressing PvNCEDl (Phaseolous vulgaris) similarly showed lower water loss by transpiration (Qin and Zeevaart, 2002). Enhanced stomatal closure was also observed in transgenic lines of Vicia fava expressing the AtNCED3 gene (Melhorn et al., 2008). This might also have occurred with the GM event $2 \mathrm{Ha} 11$ in the present study, since reduced values of gas exchange parameters were observed under WD conditions (Figure 2). ABA has been widely reported as an inducer of stomatal closure with the aim of reduces water loss by transpiration. This was probably the mechanism activated in all these plants to enhance drought tolerance, i.e. a decrease in stomatal aperture triggered by an increase of the ABA levels.

As observed for the GM event $2 \mathrm{Ha} 11$, an increase in yield components was reported in GM lines of creeping bent grass overexpressing $V u N C E D 1$, which showed increased plant body biomass with increased number of tillers under water deficit conditions (Aswath et al., 2005). Final yield is composed by three parameters, which are number of pods per unit area, number of seeds per pod and average grain weight. Although these components were not presented individually, the higher final yield of GM $2 \mathrm{Ha} 11$ can be explained by the combination of these three components. For grain crops, a successful selection approach would eventually be determined by the reproductive achievement and by the final yield (Saint et al., 2012). Therefore, it is very important to trial NCED plants in field conditions, as few studies have described results from GM crops cultivated in genuine field conditions (Passioura, 2012; Saint et al., 2012). In the present study, in a field-experiment, in crop season 2015/16, in relation to its background, the GM event $2 \mathrm{Ha} 11$ showed increased yield (Figure 4B), which was probably a result of higher 100-seeds weight (Figure 4A) and total number of pods (Figure 5). Some authors (Rolla et al., 2013; Fuganti-Pagliarini et al., 2017) have also described experiments for soybean GM lines under field conditions in four different water regimes; irrigation, drought (rain-fed) and water deficit treatment induced through rainout shelters at vegetative or reproductive stages. As reported here, the GM plants showed increased yield components when drought was induced. It is also important to highlight that Molinari et al. (2018) reported no differences among the NCED GM lines and background cultivar in seedling, also an important phase that can be impaired by water deficit and results in low final yield. Yet, no phenotype differences were identified in the GM plants submitted to drought-experiments under greenhouse and field conditions.

The results obtained here from molecular and physiological studies in greenhouse and field conditions confirm the potential of overexpressing $N C E D$ gene to improve drought tolerance in soybean and suggest that the AtNCED3 soybean plants might outperform under drought, reducing economic and yield losses, thus being a good candidate line to be incorporated in the soybean-breeding program to develop drought-tolerant cultivars.

\section{Acknowledgments}

The authors would like to thank the National Council for Scientific and Technological Development (CNPq) for the scholarships granted to Postdoctoral fellows R FugantiPagliarini, LC Ferreira and J Marcolino-Gomes and The Coordination for the Improvement of Higher Education Personnel (CAPES-Brasil, Finance code 001) for a Master's scholarship granted to MDC Molinari. This work was supported by the Science and Technology Research Partnership for Sustainable Development (SATREPS) of the Japan Science and Technology Agency/Japan International Cooperation Agency.

\section{Conflict of Interest}

The authors declare that there is no conflict of interest.

\section{Authors Contributions}

MDCM and RFP conceived the study, participated in every stage, analyzed all obtained data and wrote the manuscript; SRRM performed the gene expression analysis; LCF 
analyzed the physiological data and contributed with the physiological writing; DAB and JMG directly helped in conducting and collecting data from experiments in greenhouse and field conditions; MCNO carried out statistical analysis; LMMM participated in the ABA concentration analysis; NK performed the transformation processes to obtain GM lines; HT and KU produced the genetic construct with AtNCED3 gene; KS, KN and KYS are research partners from Japanese institutes, which isolated the gene from $A$. thaliana and revised the manuscript; ALN is the team's leading researcher and reviewed the final version of the manuscript. The final revision was read and approved for all authors.

\section{References}

Agustí J, Zapater M, Iglesias DJ, Cercós M, Tadeo FR and Talón M (2007) Differential expression of putative 9-cis-epoxycarotenoid dioxygenases and abscisic acid accumulation in water stressed vegetative and reproductive tissues of citrus. Plant Sci 172:85-94.

Ahrazem O, Rubio-Moraga A, Trapero A and Gómez-Gómez L (2012) Developmental and stress regulation of gene expression for a 9-cis-epoxycarotenoid dioxygenase, CstNCED, isolated from Crocus sativus stigmas. J Exp Bot 63:681-694.

Aswath CR, Kim SH, Mo SY and Kim DH (2005) Transgenic plants of creeping bent grass harboring the stress inducible gene, 9-cis-epoxycarotenoid dioxygenase, are highly tolerant to drought and $\mathrm{NaCl}$ stress. Plant Growth Regul 47:129-139.

Bao G, Zhuo C, Qian C, Xiao T, Guo Z and Lu S (2016) Co-expression of NCED and $A L O$ improves vitamin $\mathrm{C}$ level and tolerance to drought and chilling in transgenic tobacco and stylo plants. Plant Biotechnol J 14:206-214.

Barbosa EG, Leite JP, Marin SR, Marinho JP, Carvalho JD, Fuganti-Pagliarini R, Farias JR, Neumaier N, Marcelino-Guimarães FC, de Oliveira MC et al. (2013) Overexpression of the ABA-dependent AREB1 transcription factor from Arabidopsis thaliana improves soybean tolerance to water deficit. Plant Mol Biol Rep 31:719-730.

Behnam BA, Iuchi SA, Fujita MI, Fujita YA, Takasaki HI, Osakabe YU, Yamaguchi-Shinozaki KA, Kobayashi MA and Shinozaki KA (2013) Characterization of the promoter region of an Arabidopsis gene for 9-cis-epoxycarotenoid dioxygenase involved in dehydration-inducible transcription. DNA Res 20:315-324.

Berlato MA, Matzenauer R and Bergamaschi H (1986) Evapotranspiração máxima da soja e relações com a evapotranspiração calculada pela equação de Penman, evaporação de tanque "classe A" e radiação solar global. Agronomia Sulriograndense 22:243-259.

Burbidge A, Grieve TM, Jackson A, Thompson A, McCarty DR and Taylor IB (1999) Characterization of the ABA-deficient tomato mutant notabilis and its relationship with maize Vp14. Plant J 17:427-431.

Bhaskara GB, Nguyen TT and Verslues PE (2012) Unique drought resistance functions of the highly ABA-induced clade A protein phosphatase 2Cs. Plant Physiol 160:379-395.

Brock MT and Galen C (2005) Drought tolerance in the alpine dandelion, Taraxacum ceratophorum (Asteraceae), its exotic congener T. officinale, and interspecific hybrids under natural and experimental conditions. American Journal of Botany 92:1311-1321.
Cao M, Liu X, Zhang Y, Xue X, Zhou XE, Melcher K, Gao P, Wang F, Zeng L, Zhao Y et al. (2013) An ABA-mimicking ligand that reduces water loss and promotes drought resistance in plants. Cell Res 23:1043-1054.

Casali N and Preston A (2003) E. coli Plasmid vectors. Plasmid 235:55-69.

Chan Z (2012) Expression profiling of ABA pathway transcripts indicate crosstalk between abiotic and biotic stress responses in Arabidopsis. Genomics 100:110-115.

Chaves MM, Flexas J and Pinheiro C (2009) Photosynthesis under drought and salt stress: Regulation mechanisms from whole plant to cell. Ann Bot 103:551-560.

Chernys JT and Zeevaart JAD (2000) Characterization of the 9-cisepoxycarotenoid dioxygenase gene family and the regulation of abscisic acid biosynthesis in avocado. Plant Physiol 124:343-353.

Dominguez A, Fagoaga C, Navarro L, Moreno P and Peña L (2002) Regeneration of transgenic citrus plants under nonselective conditions result in high-frequency recovery of plants with silenced transgenes. Mol Genet Genomics 267:544-556.

Doyle JJ and Doyle JL (1987) A rapid DNA isolation procedure for small quantities of fresh leaf tissue. Phytochemistry Bull 19:11-15.

Endo A, Sawada Y, Takahashi H, Okamoto M, Ikegami K, Koiwai H, Seo M, Toyomasu T, Mitsuhashi W, Shinozaki K et al. (2008) Drought induction of Arabidopsis 9-cis-epoxycarotenoid dioxygenase occurs in vascular parenchyma cells. Plant Physiol 147:1984-1993.

Fehr WR, Caviness CE, Burmood DT and Pennington JS (1971) Stage of development description for soybeans, Glycine max (L.) Merril. Crop Sci 11:929-931.

Furihata T, Maruyama K, Fujita Y, Umezawa T, Yoshida R, Shinozaki K and Yamaguchi-Shinozaki K (2006) Abscisic aciddependent multisite phosphorylation regulates the activity of a transcription activator AREB1. Proc Natl Acad U S A 103:1988-1993.

Fuganti-Pagliarini R, Ferreira LC, Rodrigues FA, Molinari HB, Marin SR, Molinari MD, Marcolino-Gomes J, Mertz-Henning LM, Farias JR, de Oliveira MC et al. (2017) Characterization of soybean genetically modified for drought tolerance in field conditions. Front. Plant Sci 8:448.

Flexas J, Bota J, Loreto F, Cornic G and Sharkey TD (2004) Diffusive and metabolic limitations to photosynthesis under drought and salinity in C3 plants. Plant Biol 6:269-279.

Hood EE, Gelvin SB, Melchers LS and Hoekema A (1993) New agrobacterium helper plasmids for gene transfer to plants. Transgenic Res 2:208-218.

Fuganti-Pagliarini R, Ferreira LC, Rodrigues FA, Molinari HB, Marin SR, Molinari MD, Marcolino-Gomes J, Mertz-Henning LM, Farias JR, de Oliveira MC et al. (2016) Molecular, physiological and agronomical characterization, in greenhouse and in field conditions, of soybean plants genetically modified with AtGolS2 gene for drought tolerance. Mol Breeding 36:157.

Hubbard KE, Nishimura N, Hitomi K, Getzoff ED and Schroeder JI (2010) Early abscisic acid signal transduction mechanisms: Newly discovered components and newly emerging questions. Gene Dev 24:1695-1708.

Iuchi S, Kobayashi M and Yamaguchi-Shinozaki K (2000) A stress-inducible gene for 9-cis-epoxycarotenoid dioxigenase involved in abscisic acid biosynthesis under water stress in drought-tolerance cowpea. Plant Physiol 123:553-562.

Iuchi S, Kobayashi M, Taji T, Naramoto M, Seki M, Kato T, Tabata S, Kakubari Y, Yamaguchi-Shinozaki K and Shinozaki K 
(2001) Regulation of drought tolerance by gene manipulation of 9-cis-epoxycarotenoid dioxygenase, a key enzyme in abscisic acid biosynthesis in Arabidopsis. Plant J 27:325-333.

Kim TH, Böhmer M, Hu H, Nishimura N and Schroeder JI (2010) Guard cell signal transduction network: Advances in understanding abscisic acid, $\mathrm{CO}_{2}$, and $\mathrm{Ca}+$ signaling. Annu Rev Plant Biol 61:561-591.

Koiwai H, Nakaminami K, Seo M, Mitsuhashi W, Toyomasu T and Koshiba T (2004) Tissue-specific localization of an abscisic acid biosynthetic enzyme, AAO3, in Arabidopsis. Plant Physiol 134:1697-1707.

Liu F, Andersen MN, Jacobsen SE and Jensen CR (2005) Stomatal control and water use efficiency of soybean (Glycine max L. Merr.) during progressive soil drying. Environ Exp Bot 54:33-40.

Liu T, Longhurst AD, Talavera-Rauh F, Hokin SA and Barton MK (2016) The Arabidopsis transcription factor ABIG1 relays ABA signaled growth inhibition and drought induced senescence. eLife 5:e13768.

Livak KJ and Schmittgen TD (2001) Analysis of relative gene expression data using real-time quantitative PCR and the $2^{-\Delta \Delta C t}$ method. Methods 25:402-408.

Ma Y, Szostkiewicz I, Korte A, Moes D, Yang Y, Christmann A and Grill E (2009) Regulators of PP2C phosphatase activity function as abscisic acid sensors. Science 324:1064-1068

Marin E, Nussaume L and Quesada A (1996) Molecular identification of zeaxanthin epoxidase of Nicotiana plumbaginifolia, a gene involved in abscisic acid biosynthesis and corresponding to the ABA locus of Arabidopsis thaliana. EMBO J 15:2331-2342.

Marinho JP, Kanamori N, Ferreira LC, Fuganti-Pagliarini R, Carvalho JD, Freitas RA, Marin SR, Rodrigues FA, Mertz-Henning LM, Farias JR et al. (2015) Characterization of molecular and physiological responses under water deficit of genetically modified soybean plants overexpressing the AtAREB1 transcription factor. Plant Mol Biol Rep 34:410-426.

Medrano H, Tomás M, Martorell S, Flexas J, Hernández E, Rosselló J and Bota J (2015) From leaf to whole-plant water use efficiency (WUE) in complex canopies: Limitations of leaf WUE as a selection target. The Crop Journal 3:220-228.

Melhorn V, Matsumi K, Koiwai H, Ikegami K, Okamoto M, Nambara E, Bittner F and Koshiba T (2008) Transient expression of AtNCED3 and AAO3 genes in guard cells causes stomatal closure in Vicia faba. J Plant Res 121:125-131.

Meyer R, Candrian U and Luè-Thy J (1994) Detection of pork in heated meat products by polymerase chain reaction (PCR). J AOAC Int 77:617-622.

Miyakawa T, Fujita Y, Yamaguchi-Shinozaki K and Tanokura M (2013) Structure and function of abscisic acid receptors. Trends Plant Sci 18:259-266.

Molinari MDC, Fuganti-Pagliarini R, Barbosa DA, Andreatta EC, Nepomuceno AL and Hertz-Henning LM (2018) Seleção de sementes de soja geneticamente modificadas com o gene marcador bar por meio do teste de germinação em solução de glufosinato de amônio. Rev Cienc Agrar 61:1-7.

Nakashima K and Yamaguchi-Shinozaki K (2013) ABA signaling in stress-response and seed development. Plant Cell Rep 32:959-970.

Nambara E and Marion-Poll A (2005) Abscisic acid biosynthesis and catabolism. Annu Rev Plant Biol 56:165-185.

Neves DM, Coelho Filho MA and Bellete BS (2013) Comparative study of putative 9-cis-epoxycarotenoid dioxygenase and abscisic acid accumulation in the responses of Sunki manda- rin and Rangpur lime to water deficit. Mol Biol Rep 40:5339-5349.

Oltmanns H, Frame B, Lee LY, Johnson S, Li B, Wang K and Gelvin SB (2010) Generation of backbone- free, low transgene copy plants by launching T-DNA from the agrobacterium chromosome. Plant Physiol 152:1158-1166.

Park SY, Fung P, Nishimura N, Jensen DR, Fujii H, Zhao Y, Lumba S, Santiago J, Rodrigues A, Tsz-fung et al. (2009) Abscisic acid inhibits type 2C protein phosphatases via the PYR/PYL family of START proteins. Science 324:1068-107.

Park SY, Peterson FC, Mosquna A, Yao J, Volkman BF and Cutler SR (2015) Agrochemical control of plant water use using engineered abscisic acid receptors. Nature 520:545-548.

Passioura JB (2012) Phenotyping for drought tolerance in grain crops: when is it useful to breeders? Funct Plant Biol 39:851859.

Paz MM, Martinez JC, Kalvig AB, Fonger TM and Wang K (2006) Improved cotyledonary node method using an alternative explant derived from mature seed for efficient Agrobacterium-mediated soybean transformation. Plant Cell Rep 25:206-213

Pedrosa AM, Martins CD, Goncalves LP and Costa MG (2015) Late embryogenesis abundant (lea) constitutes a large and diverse family of proteins involved in development and abiotic stress responses in sweet orange (Citrus sinensis L. Osb.). PloS One 10:1-17.

Pfaffl MW (2001) A new mathematical model for relative quantification in real-time RT-PCR. Nucleic Acids Res 29:e45.

Qin X and Zeevaart JA (1999) The 9-cis-epoxycarotenoid cleavage reaction is the key regulatory step of abscisic acid biosynthesis in water-stressed bean. Proc Natl Acad Sci-Biol 96:15354-15361.

Qin X and Zeevaart JA (2002) Overexpression of a 9-cis-epoxycarotenoid dioxygenase gene in Nicotiana plumbaginifolia increases abscisic acid and phaseic acid levels and enhances drought tolerance. Plant Physiol 128:544-551.

Ramiro DA, Melotto-Passarin DM, Barbosa MD, Santos FD, Gomez SG, Massola Júnior NS, Lam E and Carrer H (2016) Expression of Arabidopsis Bax Inhibitor-1 in transgenic sugarcane confers drought tolerance. Plant Biotechnol J 14:1826-1837.

Rodrigo MJ, Alquezar B and Zacarias L (2006) Cloning and characterization of two 9-cis-epoxicarotenoid dioxigenase gene, differentially regulated during fruit maturation and under stress conditions, from orange (Citrus sinensis L. Osbeck). J Exp Bot 57:633-643.

Rodrigues FA, Fuganti-Pagliarini R, Marcolino-Gomes J, Nakayama TJ, Molinari HB, Lobo FP, Harmon FG and Nepomuceno AL (2015) Daytime soybean transcriptome fluctuations during water deficit stress. BMC Genomics 16:505.

Rolla AA, Carvalho JD, Fuganti-Pagliarini R, Engels C, Rio A, Marin SR, de Oliveira MC, Beneventi MA, Marcelino-Guimaraes FC, Farias JR et al. (2013) Phenotyping soybean plants transformed with $\mathrm{rd29A}$ :AtDREB1A for drought tolerance in the greenhouse and field. Transgenic Res 23:75-87.

Sah SK, Reddy KR and Li J (2016) Abscisic acid and abiotic stress tolerance in crop plants. Front Plant Sci 7:571.

Saint Pierre C, Crossa JL, Bonnett D, Yamaguchi-Shinozaki K and Reynolds MP (2012) Phenotyping transgenic wheat for drought resistance. J Exp Bot 63:1799-1808.

Seo M, Koiwai H and Akaba S (2000) Abscisic aldehyde oxidase in leaves of Arabidopsis thaliana. Plant J 23:481-488. 
Schwartz BC, Tan DA and Gage JA (1997) Specific oxidative cleavage of carotenoids by VP14 of maize. Science 276:1872-1874.

Shinozaki K and Yamaguchi-Shinozaki K (2007) Gene networks involved in drought stress response and tolerance. J Exp Bot 58:221-227.

Takeuchi M, Okamoto T and Akiyama T (2014) Designed abscisic acid analogs as antagonists of PYL-PP2C receptor interactions. Nat Chem Biol 10:477-482.

Thompson AJ, Jackson AC, Parker RA, Morpeth DR, Burbidge A and Taylor IB (2000) Abscisic acid biosynthesis in tomato: regulation of zeaxanthin epoxidase and 9-cis-epoxycarotenoid dioxygenase mRNAs by light/dark cycles, water stress and abscisic acid. Plant Mol Biol 42:833.

Thornthwaite CW and Mather JR (1955) The water balance, vol III, n 1. Laboratory of Climatology, Centerton, NJ, 104 p.

Umezawa T, Sugiyama N, Mizoguchi M, Hayashi S, Myouga F, Yamaguchi-Shinozaki K, Ishihama Y, Hirayama T and Shinozaki K (2009) Type 2C protein phosphatases directly regulate abscisic acid-activated protein kinases in Arabidopsis. Proc Natl Acad U S A 106:17588-17593.

Umezawa T, Nakashima K and Miyakawa T (2010) Molecular basis of the core regulatory network in ABA responses: sensing, signaling and transport. Plant Cell Physiol 51:1821-1839.

Vlad F, Rubio S, Rodrigues A, Sirichandra C, Belin C, Robert N, Leung J, Rodriguez PL, Laurière C and Merlot S (2009) Protein phosphatases $2 \mathrm{C}$ regulate the activation of the Snf1related kinase OST1 by abscisic acid in Arabidopsis. Plant Cell 21:3170-3184.

Wan XR and Li L (2006) Regulation of ABA level and water-stress tolerance os Arabidopsis by ectopic expression of a peanut 9-cis-epoxycarotenoid dioxigenase gene. Biochem Bioph Res Co 347:1030-1038.

Wang X, Wang Z and Dong J (2009) Cloning of a 9-cis-epoxycarotenoid dioxygenase gene and the responses of Caragana korshinskii to a variety of abiotic stresses. Genes Genet Syst 84:397-405.

Yang J and Guo Z (2007) Cloning of a 9-cis-epoxycarotenoid dioxygenase gene (SgNCED1) from Stylosanthes guianensis and its expression in response to abiotic stresses. Plant Cell Rep 26:1383-1390.

Yang L, Liang J, Zhou W, Su L, Zhang B and Li L (2011) Isolation and characterization of the aldehyde oxidase 2 gene from Arachis hypogaea L. Plant Mol Biol Rep 29:544.

Yin C, Wang X, Duan B, Luo J and Li C (2005) Early growth, dry matter allocation and water use efficiency of two sympatric
Populus species as affected by water stress. Environ Exp Bot 53:315-322.

Yoshida T, Fujita, Y, Maruyama K, Mogami J, Todaka D, Shinozaki K and Yamaguchi-Shinozaki K (2014) Four Arabidopsis $\mathrm{AREB} / \mathrm{ABF}$ transcription factors function predominantly in gene expression downstream of SnRK2 kinases in abscisic acid signalling in response to osmotic stress. Plant Cell Environ 38:35-49.

Zhang Y, Yang J, Lu S, Cai J and Guo Z (2008) Overexpressing SgNCED1 in tobacco increases aba level, antioxidant enzyme activities, and stress tolerance. Plant Growth Regul 27:151.

Zdunek-Zastocka E and Sobczak M (2013) Expression of Pisum sativum PSAO3 gene, which encodes an aldehyde oxidase utilizing abscisic aldehyde, is induced under progressively but not rapidly imposed drought stress. Plant Physiol Bioch 71:57-66.

\section{Internet Resources}

Associação dos Produtores de Soja e Milho do Estado do Mato Grosso (Aprosoja), http://aprosojapr.com.br/sobre-a-soja/uso-da-soja/.

Empresa Brasileira de pesquisa Agropecuária - Embrapa (2010) Tecnologias de produção de soja-região central do Brasil 2011 , https://www.embrapa.br/busca-de-publicacoes/-/publicacao/ 864927/tecnologias-de-producao-de-soja-regiao-central-d o-brasil-2011.

Empresa Brasileira de pesquisa Agropecuária - Embrapa, Alimentação e Agricultura, http://www.cnpso.embrapa.br/index.php?cod_pai2andop_page294.

Instituto Brasileiro de Geografia e Estatística - IBGE, http://www.ibge.gov.br/home/presidencia/noticias/imprensa/ ppts/00000025365003112016502503588543.pdf.

\section{Supplementary material}

The following online material is available for this article:

Figure S1 - Plasmid pC3300J-35S-AtNCED3.

Figure S2 - Water balance from crop seasons 2015-2016 and 2016-2017.

Table S1 - Chi-square $\left(\mathrm{X}^{2}\right)$ test for Mendelian segregation pattern.

Associate Editor: Marcio C. Silva-Filho

License information: This is an open-access article distributed under the terms of the Creative Commons Attribution License (type CC-BY), which permits unrestricted use, distribution and reproduction in any medium, provided the original article is properly cited. 